\title{
Great American Egret
}

(Casmerodius albus egretta)

By E. L. FOX, Regina

The Golden Jubilee Year of the Province of Saskatchewan was the occasion for an American visitor of a different kind. A pair of Great American Egrets reared a family in the marshes of the Qu'appelle Valley north of the city of Regina. Following several reports in the early summer of a white Heron in the valley, thought to be an albino or dilute of the Great Blue (Ardea herodias), I decided to investigate. On my third trip I was lucky.

At 3.10 p.m. on August 30, 1955, I saw a large white Heron feeding in the marsh about half a mile distant. I tentatively identified it as the Great American Egret. The bird flew up and away, passing within one quarter mile as it did so. As it flew. I noted the Heron shape. the black legs, and the lack of any black on the wing tips. I was now fairly sure of my first impression, but far from satisfied. I decided to proceed further west down the valley; at 3.55 $\mathrm{pm}$. at a point about seven miles from my first observation, I saw two Egrets a short distance off the road. I approached through a line of trees to within less than sixty yards where I observed the birds through $7 \mathrm{x}$ binoculars. One was standing in about three inches of water, and the other perched on the linb of a dead tree just over the water. All the points of identification were noted: the black legs and feet and the yellowish-orange bill. As I watched, a Great Blue Heron flew in beside them and I noted the Egret is slightly smaller than his blue relative.

On September 3, 1955, Fred Lahrman of the Provincial Museum and I took a trip to the valley to attempt to obtain some pictures. After some difficultly, owing to the birds' wariness and lack of cover for us, several pictures were taken. They were taken at a distance of about one hundred yards with a telephoto lens.

Later in the day we talked to a farmer in the area who showed us where the nest had been. He told us of his observations during the summer. Perched on a nearby hillside, using a pair of binoculars, he had on several occasions observed the birds at the nest site. He had watched the birds sitting on the nest and saw them feeding the young. He stated that there had been three young birds in the nest. This number was later confirmed as I made a trip to the area a short time later. Accompanied by John A. Livingston, executive director of the Audubon Society of Canada and member of the Toronto bird club, I observed five Egrets together. Although there is no noticeable difference in the plumage between adult and juvenile, considerable difference in size was noted.

The American Egret has been a most welcome visitor to the valley. It is interesting to compare our record of the Egret in the Qu'Appelle with other reports of the extension of their range. In the Audubon Field Notes' spring migration survey, 1955, Ludlow Griscom notes the steadily increasing numbers of the southern Herons and the fact that they are pushing northward. In the survey, American Egrets were reported nesting in a colony of Great Blues near Hastings, Minnesota, this spring - about the fourth repcrt of American Egrets nesting in Minnesota. The seasonal report in the September 1955 Flicker mentions American Egrets seen in fairly large numbers in Minnesota, again in August. Mr. Dick Sutton, Director of the Manitoba Museum, reports that American Egrets nested in Manitoba this year. Ideal nesting and feeding conditions have no doubt contributed to the northward migration of the species. The abnormal rainfall during the past several years has created a huge marsh area in the valley where no marsh area previously $\epsilon$ xisted. It is to be hoped that the American Egret returns to the valley in 1956. If it does, I for one intend to delve further into the homelife of this interesting bird.

E. L. Fox

\section{CHRISTMAS GIFT SUGGESTION}

Back copies of the 1954 and 1955 Blue Jays are available. These may be obtained, all eight issues, for only one dollar or four issues, either 1954 or 1955, may be obtained for fifty cents. Send in your order now to Mr. E. L. Fox, 1053 Gladmer Park, Regina. 